\title{
Green conveyor on the basis of perennial grasses and mixtures of annual crops
}

\author{
Ya. Tsymbal, \\ PhD, scientific associate \\ National scientific center "Institute of Agriculture of NAAS"
}

The purpose. To determine the best perennial leguminous grasses and mixtures of annual crops at organic and mineral fertilizing, and to develop technological measures of production of feed raw material with continuous uniform receipt of vegetable mass for manufacture of ecologically safe grassy feedstuff for cattle on dark grey podzolized soils. Methods. Systems analysis, field, laboratory, analytical, mathematical-andstatistical, calculation-and-comparative. Results. They determined the best sorts of perennial grasses and mixtures of annual crops for feeding cattle. Technological measures of production of feed raw material are developed. High productivity and quality is proved. On the basis of the research the model of green (raw) conveyor is developed. Conclusions. The developed model of green (raw) conveyor for feeding 100 animals of cattle on the area of 56 hectares allows continuous provision of animals with green material within 144 days and with hay and silo - in the winter.

Key words: perennial and annual grasses, ecologically safe feedstuff, models of green (raw) conveyors.

Production of cheap milk and meat especially for dietary and baby food depends on making of full-grown herbal forages for cattle. The main part in fodder production has growing of perennial fabaceous grasses and annual forage crops and annual forage crop mixes and optimization of growing technologies in system of green (row material) conveyor.

But these technologies not always supply appropriate quality of forages according to modern state standards specifications. That's why in context of improving of people supply by qualitative meat and dairy production in last years has occurred necessity in developing of technology operations with aim of providing of animal husbandry by cheap high-quality herbal forages, among of them the main part play methods of biological forage row material production, usage of energy-saving technologies of production, properly developed planning sheets and models of green (row material) conveyors and other, which remains not properly well-tried.

Aim of work is determining better perennial fabaceae grasses and mixes of annual crops on organic and mineral fertilizing and improving of technological operations of forage row material production with continuous proportional income of vegetable matter for production of ecologically-safe herbal forages on dark-grey podzolized soils.

Methods of research. On the generalization of literature sources determined the courses of developing of organic forage production. Investigation of mechanism of formation of productivity of perennial fabaceae grasses and mixes of annual crops in system of green conveyers of organic production of forage row material we were conducted in SE "Scientific farming Chabany" of NSC "Institute of Agriculture NAAS" of dark-gray podzolized soil by standard methodic of researches.

In experiment were conducted researches of comparative productivity of different species of fabaceae grasses on three backgrounds of fertilizing according to scheme. Preparation "Wuksal-Microplant", which is consist of macro and microelements mix in form of chelate were introduced by spraying of plants top in tillering stage of grasses in 1-st and 2-nd mowing in concentration $2 \mathrm{l} / \mathrm{ha}$. On cereal herbage additionally introduced the nitrogen of mineral fertilizers in doze $N_{\mathbb{N}}$ in two stages. Investigation of productivity and quality of herbage which consist of annual crops mixes in main and after-mowing sowing conducted by 
various fertilizing systems: organic with input of complex granulated organic manure Humigran in doze 250 $\mathrm{kg} / \mathrm{ha}$ and mineral with introducing of mineral fertilizers in doze $\mathrm{N}_{\mathrm{P}} \mathrm{P}_{\mathrm{j}} \mathrm{K}_{\mathrm{s}}$.

Results of investigations. The main task of green and row material conveyers are uninterrupted providing of cattle feeding by green forages in spring-summer and summer-autumn periods, and row material for production of hay, haylage, silage or dry forages in winter period.

In developing of green (row material) conveyers necessary to take into consideration biological characteristics and earliness of grasses, ecological conditions, planting locality, and economical effectiveness of it growing and complex of agro-technical operations (choice of grasses or mixes, selection of plots, fertilizing and moistening usage regime), and range of organizational actions of creating, herbage management and usage [1, 2, 3, 4]. The area for green and row material conveyors selected not far from farm or forage storage site with developed access road. Moreover, in the organization conveyor accounted the quality of forage, the time of the mass income, yielding, daily needs of animals and other factors [5].

In addition to the above indicators in the creation of green conveyors take into account the way of the animals keeping (stall or pasture) and the rational use of herbage. There are several systems for using herbage: mowing, pasture and mowing-pasture.

The main criteria of green and raw conveyors are: compliance with the requirements green mass standards for quality; extension of the continuous income of green mass; high performance 1 ha of forage area; the simplicity of the organization conveyor $[5,6]$.

According to the results of the data obtained in our research, we stopped at the organization of production of different types of perennial grasses and mixtures of annual crops of which we get high-quality grass forage (hay, haylage, silage and green fodder) in the system green and raw material conveyors on a basis of feed production from the field.

We have developed a model of green and raw material conveyer based on perennial legume grasses without fertilization and mixes of annual crops of organic granular fertilizer Humihran on dark gray podzolized soils on natural humidification for feeding of 100 heads of cattle. This type of model can provide a continuous income of green mass for 144 days (Table. 1) for participation in the conveyor of grass species like red clover (variety Polyanka), Lotus corniculatus (variety of Ajax), alfalfa crop (variety Olha), alfalfa yellow (Narechena pivnochi), Bromus inermis (variety Arsen).

This conveyor is universal. It can be used for the production of green fodder, hay or silage involving mixtures of perennial grasses and annual crops for green fodder, hay and silage. In developing the model of green and raw material conveyer we stopped in the production of green mass and hay.

One of the ways to improve fodder products is the creation and use of herbages with various ripeness time and development on their basis of this type of conveyors. The establishment of such conveyors should consider the timing of the onset of harvest maturity of species and varieties or mixtures thereof. Therefore, it is widely used not only grass mixes, but mixes of varieties with different mowing maturity dates, especially in the United States, Great Britain and other countries $[7,8,9,10]$.

Therefore there is a need for the maximum elongation green or raw material conveyor in early spring and late autumn periods and for closing the "windows" that arising from the use different ripening perennial grasses. This role is designed to perform our conveyor grass mixtures of annual crops, which are overlap the free zones between mowings of perennial legumes (Table. 1).

Mixtures of annual crops were cultivated for making granular organic fertilizer Humihran for direct feeding in the stabling of 100 heads of cattle. This conveyor involved are mainly mixtures annual crops like oats (variety Parliament) from spring vetch (variety Yaroslav), spring triticale (variety Arsenal) with winter rape (variety Senator-Luks) for early spring use; hybrid corn (variety Horol SB) of Lupinus angustifolius (variety Hlatko), Sudan sorghum (variety Holubivskyy) with the field pea (variety Fundator), Japanese millet Echinochloa frumentacea (variety Nadiya) with oil radish (variety Lybid) for average term use; and aftermowing crops (after vetch-oat and triticale-canola mixtures in major crops) with the participation of Japanese millet and oil radish and from the Sudanese sorghum with oil radish — for more later use.

Table 1 shows the model of green and raw material conveyor that provides full 100 head of cattle the green mass and the excess is used in harvesting and production of hay or haylage, silage for winter 
maintenance. The model of green and raw material conveyor showed that full maintenance of the dairy cattle in livestock sector by way of stabling required land amounting to 56 hectares. Selected species and varieties of herbages allow obtain high-productive green mass with good quality with minimal involvement of fertilizers that fully meets modern requirements for organic production and allows obtaining a sufficient yield with minimum expenses.

Table 1. Model of green (raw material) conveyor on the basis of perennial grasses for two, threemowing use of annual crops mixtures for feeding in stabling of 100 heads of cattle in livestock dairy complex and laying-in hay or silage

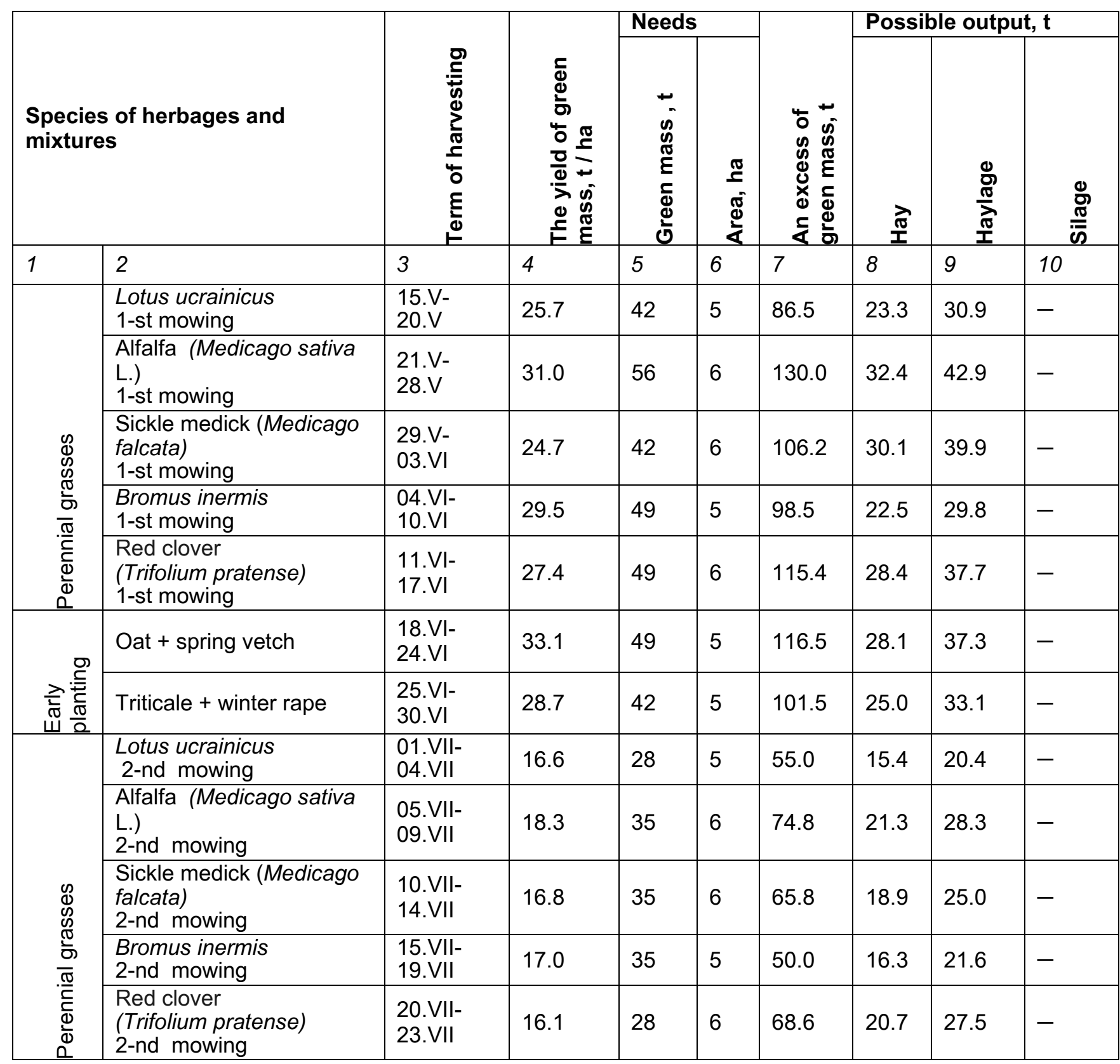




\begin{tabular}{|c|c|c|c|c|c|c|c|c|c|}
\hline \multirow{3}{*}{ 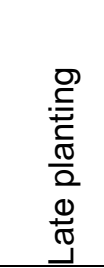 } & $\begin{array}{l}\text { Japanese millet - } \\
\text { (Echinochloa } \\
\text { frumentacea) + oil radish }\end{array}$ & $\begin{array}{l}\text { 24.VII- } \\
02 . \mathrm{VIII}\end{array}$ & 59.9 & 70 & 6 & 289.4 & - & - & 85.0 \\
\hline & $\begin{array}{l}\text { Maize + blue lupine } \\
\text { (Lupinus angustifolius) }\end{array}$ & $\begin{array}{l}\text { 03.VIII- } \\
\text { 12.VIII }\end{array}$ & 59.5 & 70 & 6 & 287.0 & - & - & 107.3 \\
\hline & $\begin{array}{l}\text { Sudan sorghum + field } \\
\text { pea }\end{array}$ & $\begin{array}{l}\text { 13.VIII- } \\
\text { 20.VIII }\end{array}$ & 55.3 & 56 & 6 & 275.8 & - & - & 106.0 \\
\hline \multirow{3}{*}{ 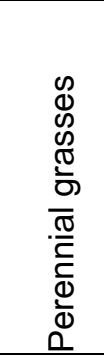 } & $\begin{array}{l}\text { Alfalfa (Medicago sativa } \\
\text { L.) } \\
\text { 3-d mowing }\end{array}$ & $\begin{array}{l}\text { 21.VIII- } \\
\text { 27.VIII }\end{array}$ & 11.2 & 49 & 6 & 18.2 & 6.1 & 8.1 & - \\
\hline & $\begin{array}{l}\text { Sickle medick (Medicago } \\
\text { falcata) } \\
\text { 3-d mowing }\end{array}$ & $\begin{array}{l}\text { 28.VIII- } \\
\text { 03.IX }\end{array}$ & 9.5 & 49 & 6 & 8.0 & 2.4 & 3.1 & - \\
\hline & $\begin{array}{l}\text { Red clover } \\
\text { (Trifolium pratense) } \\
\text { 3-d mowing }\end{array}$ & $\begin{array}{l}04 . I X- \\
09.1 X\end{array}$ & 8.9 & 42 & 6 & 11.4 & 3.5 & 4.7 & - \\
\hline \multirow{2}{*}{ 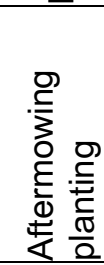 } & $\begin{array}{l}\text { Japanese millet - } \\
\text { (Echinochloa } \\
\text { frumentacea) + oil radish }\end{array}$ & $\begin{array}{l}\text { 10.IX- } \\
17 . I X\end{array}$ & 38.0 & 56 & 5 & 134.0 & - & - & 43.4 \\
\hline & $\begin{array}{l}\text { Sudan sorghum + oil } \\
\text { radish }\end{array}$ & $\begin{array}{l}\text { 18.IX- } \\
27 . I X\end{array}$ & 64.6 & 70 & 5 & 253.0 & - & - & 99.3 \\
\hline \multicolumn{2}{|c|}{ After-grass of Sudan sorghum } & $\begin{array}{l}28 . I X- \\
05 . X\end{array}$ & 20.0 & 56 & 6 & 64.0 & - & - & 18.0 \\
\hline \multicolumn{2}{|l|}{ Total } & 144 days & & 1008 & 56 & 2409 & 294 & 390 & 459 \\
\hline \multicolumn{10}{|c|}{$\begin{array}{l}\text { * Note: mowing of perennial grasses were carried out in the phases of budding beginning-start of blossom and } \\
\text { starting of earing }\end{array}$} \\
\hline \multicolumn{10}{|c|}{$\begin{array}{l}\text { ** Note: mowing of mixtures annual grasses was carried out by a dominant component in the phases budding- } \\
\text { start of flowering at legumes or early heading (panicle ejection) in the grass and start flowering in oil crops } \\
\text { *** Note: daily requirement per head of cattle }-70 \mathrm{~kg} \text { of green mass, } 7 \mathrm{~kg} \text { of hay, } 35 \mathrm{~kg} \text { of haylage, } 15 \mathrm{~kg} \text { of } \\
\text { silage, the group of } 100 \text { heads needs to } 7 \text { tons of green mass, } 0.7 \text { tons of hay, } 3.5 \text { tons of haylage and } 1.5 \mathrm{t} \text { of } \\
\text { silage }\end{array}$} \\
\hline
\end{tabular}

An excess of green mass we calculated that fully provides the cattle with hay and silage in winter maintenance. The need for green mass based the daily requirement per head includes 1008 tons per 144 days for feeding of 100 heads of cattle.

According to the generalized data approximate daily rate during the summer period (180 days) is $70 \mathrm{~kg}$ of green mass per head of cattle. And in the winter period (180 days) in the diet of one head of cattle per day includes: roughage (hay) - $7 \mathrm{~kg}$; succulent feed (hay - $35 \mathrm{~kg}$ and silage - $15 \mathrm{~kg}$ ) - $50 \mathrm{~kg}$ [11].

An excess of green mass of 2409.6 tons, which can be obtained 294.4 tons of hay or 390.3 tons of haylage and 459 tons of silage. According to the daily needs, hay will last for 420 days, haylage - 111 days and silage - 306 days, which generally allows for feeding the raw material all year.

Besides green fodder, hay or haylage or of silage in the diet of animals injected concentrated food also. For simplification the purchase of sowing material, you can use the same crops, involved in the pipeline, such as oats, triticale, corn, spring vetch and lupine angustifolia in pure plantings on individual land plots. Grain for these crops is grounded to fodder flour and by mixing method made of concentrated feed in optimal proportions for feeding cattle. Seeding rate of these crops for grain determined by morphological features of plants and technological growing conditions. According to many scientists in the diet of one head of cattle per day should be $2.5-3 \mathrm{~kg}$ of concentrated feeds $[12,13]$.

\section{Conclusions}

The developed model of green and raw material conveyor through a combination of perennial legume grasses without fertilization and mixes of annual crops with the introduction of Humihran on area of 56 hectares for feeding 100 heads of cattle by stall keeping mode ensures continuous flow of green mass for 144 days. The need for green mass based the daily requirement per head makes 1008 tons. An excess of green mass is 2410 tons, which can be obtained 294 tons of hay, or 390 tons of haylage and 459 tons of silage. The planned conveyor can provide these cattle by hay on $100 \%$, silage at $84 \%$ additionally. 


\section{References}

1. Ahlamova N.M. Rekomendacii po sozdaniju i intensivnomu ukosnomu ispolzovaniju travostoev $v$ Lesnoj zone evropejskoj chasti SSSR / N.M. Ahlamova, B.I. Korotkov, S.S. Lavrov i dr. // M.: Kolos, 1982. $470 \mathrm{~s}$ (in Russian).

2. Bohovin A.V. Biolohichna rol bobovykh vydiv trav u pidvyshchenni produktyvnosti luchnykh ekosystem ta nahromadzhennia nymy symbiotychnoho azotu / A.V. Bohovin, V.H. Kurhak // Zemlerobstvo. - K.: Urozhai, 1994. - Vyp. 69. - S.7-14 (in Ukrainian).

3. Kravchenko I.E. Zelenyi konveier v sovkhozakh Ukrainy / I.E. Kravchenko // Kormovaia baza. - M.:

Selkhozgiz, 1952. - № 3. - S. 11-16 (in Russian).

4. Kurhak V.H. Orhanizatsiia konveieriv na siianykh lukakh / V.H. Kurhak // Tvarynnytstvo Ukrainy. 1995. - № 4-6. - S. 26-27 (in Ukrainian).

5. Kurhak V.H. Luchni ahrofitotsenozy / V.H. Kurhak - K.: DIA, 2010. - $374 \mathrm{~s}$ (in Ukrainian).

6. Petrychenko V.F. Polove travosiiannia v systemi konveiernoho vyrobnytstva kormiv v Ukraini / V.F. Petrychenko, H.P. Kvitko // Visnyk ahrarnoi nauky. — 2004. - № 3. - S. 30-32 (in Ukrainian).

7. Minina I.P. Lugovye travosmesi / I.P. Minina // Pastbishcha i senokosy SSSR. — M.: Kolos, 1974. — S. 221-232 (in Russian).

8. Frane J. The potential of tetraploid zet clover and ist ist in the United Kingdom I / J. Frane // Brit Grosse soc, 1971. - V. 31. - № 4. - P. 139-152.

9. Vos N. Seed mixtures and varieties in the Proceedings of the 4-the General Meeting of the European Grassland Federation / N. Vos, W. Schejgrond. - Lausanne. - 1974. - P. 121-140.

10. Zee G.R. The response of seven parsing regress varies fees to application / G.R. Zee // I. Britain Grassland See. - 1976. - V. 30. - № 1. -42 p.

11. Skotarstvo. // Za red. kandydata silskohospodarskykh nauk I.H. Zorina. — K.: Urozhai, 1973. — $408 \mathrm{~s}$ (in Ukrainian).

12. Dmitrochenko A.P. Kormlenie sel'skohozjajstvennyh zhivotnyh / A.P. Dmitrochenko, P.D. Pshenichnyj. — Izd. s/h lit., zhurnalov i plakatov. — Leningrad, Moskva, 1961. — S. 180-182 (in Russian). 13. Nusov N.I. Skotovodstvo / N.I. Nusov, G.G. Ignatenko. - M.: Kolos, 1968. - S. 199-206(in Russian). 